Article

\title{
Supported Pd-Au Membrane Reactor for Hydrogen Production: Membrane Preparation, Characterization and Testing
}

\author{
Adolfo Iulianelli ${ }^{1, *}$, Marjan Alavi ${ }^{1,2}$, Giuseppe Bagnato ${ }^{1}$, Simona Liguori ${ }^{3}$, Jennifer Wilcox ${ }^{3}$, \\ Mohammad Reza Rahimpour ${ }^{2}$, Reza Eslamlouyan ${ }^{2}$, Bryce Anzelmo ${ }^{3}$ and Angelo Basile ${ }^{1, *}$ \\ 1 Institute on Membrane Technology of the Italian National Research Council (TM-CNR), Cubo 17/C, \\ University of Calabria, Rende 87036, Italy; marjan.alavi@ymail.com (M.A.); gb_87@hotmail.it (G.B.) \\ 2 Department of Chemical Engineering, School of Chemical and Petroleum Engineering, Shiraz University, \\ Shiraz 71345, Iran; rahimpor@shirazu.ac.ir (M.R.R.); eslamlo@shirazu.ac.ir (R.E.) \\ 3 Department of Energy Resources Engineering, Stanford University, Stanford 94305, CA, USA; \\ sliguori@stanford.edu (S.L.); wilcoxj@stanford.edu (J.W.); brlz@stanford.edu (B.A.) \\ * Correspondence: a.iulianelli@itm.cnr.it (A.I.); a.basile@itm.cnr.it (A.B.); Tel.: +39-0984-492-013 (A.B.); \\ +39-0984-492-011 (A.I.); Fax: +39-0984-402-103 (A.I. \& A.B.)
}

Academic Editor: Raffaele Molinari

Received: 16 March 2016; Accepted: 22 April 2016; Published: 9 May 2016

\begin{abstract}
A supported Pd-Au ( $\mathrm{Au} 7 \mathrm{wt} \%$ ) membrane was produced by electroless plating deposition. Permeation tests were performed with pure gas $\left(\mathrm{H}_{2}, \mathrm{H}_{2}, \mathrm{~N}_{2}, \mathrm{CO}_{2}, \mathrm{CH}_{4}\right)$ for long time operation. After around $400 \mathrm{~h}$ under testing, the composite $\mathrm{Pd}-\mathrm{Au}$ membrane achieved steady state condition, with an $\mathrm{H}_{2} / \mathrm{N}_{2}$ ideal selectivity of around 500 at $420^{\circ} \mathrm{C}$ and $50 \mathrm{kPa}$ as transmembrane pressure, remaining stable up to $1100 \mathrm{~h}$ under operation. Afterwards, the membrane was allocated in a membrane reactor module for methane steam reforming reaction tests. As a preliminary application, at $420{ }^{\circ} \mathrm{C}, 300 \mathrm{kPa}$ of reaction pressure, space velocity of $4100 \mathrm{~h}^{-1}, 40 \%$ methane conversion and $35 \%$ hydrogen recovery were reached using a commercial $\mathrm{Ni} / \mathrm{Al}_{2} \mathrm{O}_{3}$ catalyst. Unfortunately, a severe coke deposition affected irreversibly the composite membrane, determining the loss of the hydrogen permeation characteristics of the supported Pd-Au membrane.
\end{abstract}

Keywords: $\mathrm{Pd}-\mathrm{Au}$ membrane; methane steam reforming; composite membrane; hydrogen production

\section{Introduction}

The current development in energy use is oriented towards reducing carbon consumption due to its environmental pollution. Hydrogen as a clean and sustainable energy carrier has gained more attention during the past decades. When hydrogen reacts with oxygen in fuel cells and internal combustion engines, a large amount of energy is released explosively in heat engines and quietly in fuel, releasing water as the product.

The present source of hydrogen comes mainly from synthesis gas, which is a mixture of $\mathrm{H}_{2}$, $\mathrm{CO}$ and $\mathrm{CO}_{2}$, and it is produced by breaking the strong $\mathrm{C}-\mathrm{H}$ bonds $(439 \mathrm{~kJ} / \mathrm{mol})$ of hydrocarbons in reforming reactions. Afterwards, hydrogen is purified and separated by different energy intensive steps. A membrane reactor (MR) technology can represent an energetically efficient option to the conventional processes, with the practical advantages of a smaller footprint and capital cost reduction. In this alternative reformer, the hydrogen is produced and continuously removed from the reaction side for permeation through a hydrogen perm-selective membrane, shifting the reaction towards further product formation. As a consequence, the conversion increases and pure hydrogen is produced at the same time. 
In the specialized literature, porous carbon, silica and zeolite membranes have been used for hydrogen separation [1-3]. Nevertheless, their separation characteristics are still not acceptable although their cost is relatively low. Dense membranes made of palladium (Pd) are able to separate hydrogen from a gas mixture by a solution-diffusion mechanism with a theoretically infinite hydrogen perm-selectivity [4]. As it is well known, the cost of Pd-membranes is relatively high, but it can be reduced by depositing a thin Pd layer on a metallic or ceramic support [5].

Despite of the great permeation characteristics of $\mathrm{Pd}$, its application is restricted by some factors. Hydrogen embrittlement of Pd-membranes occurs when the operating conditions are below $300{ }^{\circ} \mathrm{C}$ and 2.0 MPa. In these conditions, hydrogen permeation through the membrane allows for the change of Pd lattice from $\alpha$ to $\beta$ phase, and vice versa. Several cycles from $\alpha$ to $\beta$ phase can cause the formation of cracks in the membrane lattice [6].

Furthermore, dense Pd-membranes are affected by surface contamination. Different studies have demonstrated the effects of different contaminants such as $\mathrm{CO}$ [7-10], $\mathrm{H}_{2} \mathrm{O}$ [11-13], $\mathrm{Cl}$ [14], $\mathrm{NH}_{3}$ [15], certain hydrocarbons and sulfur compounds like $\mathrm{H}_{2} \mathrm{~S}$ [16] on the membranes. In particular, by exposing $\mathrm{H}_{2} \mathrm{~S}$ to the Pd surface, sulfur is reversibly adsorbed on the palladium surface blocking the adsorption sites for hydrogen with a reduction in the hydrogen permeation. Sulfur can also react with the Pd surface producing $\mathrm{Pd}_{4} \mathrm{~S}$ which acts as a barrier to hydrogen permeation decreasing the permeance [17]. The lattice constants of $\mathrm{Pd}$ and $\mathrm{Pd}_{4} \mathrm{~S}$ are highly different, so this can cause cracks in the membrane [18].

In order to overcome these drawbacks, some studies proposed to change the crystal structure into nanostructure [19]. However, most of the researches proposed an enhancement of the membranes stability by alloying them with other elements [20-22]. Most efforts in this area are dedicated to $\mathrm{Pd}-\mathrm{Cu}$ alloys because of their high resistance to sulfur poisoning [23-25]. Lately, the Pd-Au membranes have been studied due to their higher hydrogen permeability with respect to $\mathrm{Pd}-\mathrm{Cu}$. In the pioneeristic study realized by McKinely et al. [26,27], it was shown that the addition of Au content in the range $0 \mathrm{w} t \%-20 \mathrm{wt} \%$ to palladium membranes enhances the tolerance to sulfur compounds, minimizing the embrittlement phenomenon and improving the hydrogen permeability more than pure Pd. In the experiments done by Way et al. [28], the Pd-15\%wt Au has exhibited a higher hydrogen permeating flux in the presence of $\mathrm{H}_{2} \mathrm{~S}$ than a Pd- $6 \%$ wt $\mathrm{Cu}$ in the absence of $\mathrm{H}_{2} \mathrm{~S}$. In particular, by using $\mathrm{Pd}-15 \% \mathrm{wt} \mathrm{Au}$ the hydrogen flux decreased $38 \%$ after the exposure to $5 \mathrm{ppm} \mathrm{H}_{2} \mathrm{~S}$ at $400{ }^{\circ} \mathrm{C}$, while, with $\mathrm{Pd}-6 \%$ wt $\mathrm{Cu}$, the hydrogen flux was 71\% lower than that measured with $\mathrm{Pd}-\mathrm{Au}$ in $\mathrm{H}_{2} \mathrm{~S}$ presence. Chen and Ma [29] examined a Pd-8\%wt $\mathrm{Au}$ on a porous metal support. In the temperature range between 350 and $500{ }^{\circ} \mathrm{C}$, no sulfide was detected in the membrane even at $54.8 \mathrm{ppm}_{2} \mathrm{~S}$ exposure.

Some studies have compared hydrogen permeation in $\mathrm{Pd}-\mathrm{Au}$ alloys with pure $\mathrm{Pd}$. Sonwane et al. [30] predicted that the hydrogen permeability in $\mathrm{Pd}-\mathrm{Au}$ membrane increased by increasing the $\mathrm{Au}$ content, having a maximum value at $12 \mathrm{wt} \% \mathrm{Au}$ and showing a hydrogen permeability 1.8 times greater than pure $\mathrm{Pd}$ at $180^{\circ} \mathrm{C}$. In other investigations, Gryaznov [31] found that the hydrogen permeability of Pd-10\%wt $\mathrm{Au}$ at $500{ }^{\circ} \mathrm{C}$ is 2.2 times higher than that of pure $\mathrm{Pd}$. Ma et al. [32] investigated the performance of several Pd-Au membranes with different Au content at $(4.2 \mathrm{wt} \%-16.7 \mathrm{wt} \%)$ from 250 to $450{ }^{\circ} \mathrm{C}$, confirming that the membranes with $4.2 \mathrm{wt} \%$ and $5.4 \mathrm{wt} \% \mathrm{Au}$ show higher hydrogen permeability than pure $\mathrm{Pd}$.

However, the stability of Pd-Au membranes under long-term operation has been tested only in a few studies, including the experimental efforts of Guazzone et al. and Mardilovich et al., who analyzed the long-term permeation test results of $\mathrm{Pd}$ and $\mathrm{Pd}-\mathrm{Au}$ composite membranes under desulfurized coal-derived syngas at pilot scale [33-35].

The objective of the present work is to investigate the long-term stability characteristics of hydrogen permeation of a composite membrane constituted of a $\mathrm{Pd}-\mathrm{Au}$ ( $\mathrm{Au} 7 \mathrm{wt} \%$ ) dense layer supported on a porous stainless steel (PSS) support, meanwhile evaluating the $\mathrm{H}_{2} / \mathrm{N}_{2}, \mathrm{H}_{2} / \mathrm{CO}_{2}$, $\mathrm{H}_{2} / \mathrm{CH}_{4}$ and $\mathrm{H}_{2} / \mathrm{He}$ ideal selectivities. 
Furthermore, at stable value of hydrogen permeance, the composite $\mathrm{Pd}-\mathrm{Au}$ membrane was allocated in a MR module for carrying out methane steam reforming (MSR) reaction for producing hydrogen and to analyze the effect of coke formation during the course of experiments.

\section{Results and Discussion}

\subsection{Permeation Tests on the Pd-Au/PSS Membrane}

The permeation tests on the supported $\mathrm{Pd}-\mathrm{Au}$ membrane at the onset of the experimental testing were carried out with pure $\mathrm{H}_{2}$ and $\mathrm{N}_{2}$ at $350{ }^{\circ} \mathrm{C}$ and transmembrane pressures of 50 and $100 \mathrm{kPa}$, with the results resumed in Table 1.

Table 1. $\mathrm{H}_{2}$ and $\mathrm{N}_{2}$ permeating flux at $350{ }^{\circ} \mathrm{C}$ with the Pd-Au/PSS membrane at the onset of the experimental testing.

\begin{tabular}{cccc}
\hline Pure gas (i) & Transmembrane Pressure (kPa) & Permeating Flux $\left(\mathbf{m o l} / \mathbf{m}^{\mathbf{2}} \cdot \mathbf{s}\right)$ & $\boldsymbol{\alpha}_{\mathbf{H} \mathbf{2} / \mathbf{i}}$ \\
\hline $\mathrm{H}_{2}$ & 50 & $3.83 \times 10^{-3}$ & 1 \\
& 100 & $8.81 \times 10^{-3}$ & \\
$\mathrm{~N}_{2}$ & 50 & $4.83 \times 10^{-5}$ & 80 \\
& 100 & $9.13 \times 10^{-5}$ & $\sim 100$ \\
\hline
\end{tabular}

As expected, a higher transmembrane pressure affects positively the hydrogen permeation driving force (in this case, represented by the hydrogen partial pressure difference between retentate and permeate sides), making higher hydrogen permeating flux achievable. Nevertheless, the results do not show high performance of the membrane in terms of $\mathrm{H}_{2} / \mathrm{N}_{2}$ ideal selectivity, which can be the consequence of defects, non-homogeneity of $\mathrm{Pd}-\mathrm{Au}$ layer or $\mathrm{Pd}-\mathrm{Au}$ alloy not yet formed. Furthermore, it is worth of noting that, at the beginning of the experimental campaign (Figure 1), the composite membrane was probably not at steady state conditions. This should justify why the $\mathrm{H}_{2} / \mathrm{N}_{2}$ ideal selectivity trend increases slightly by increasing the transmembrane pressure from $\Delta \mathrm{p}=50 \mathrm{kPa}$ to $\Delta \mathrm{p}=100 \mathrm{kPa}$.

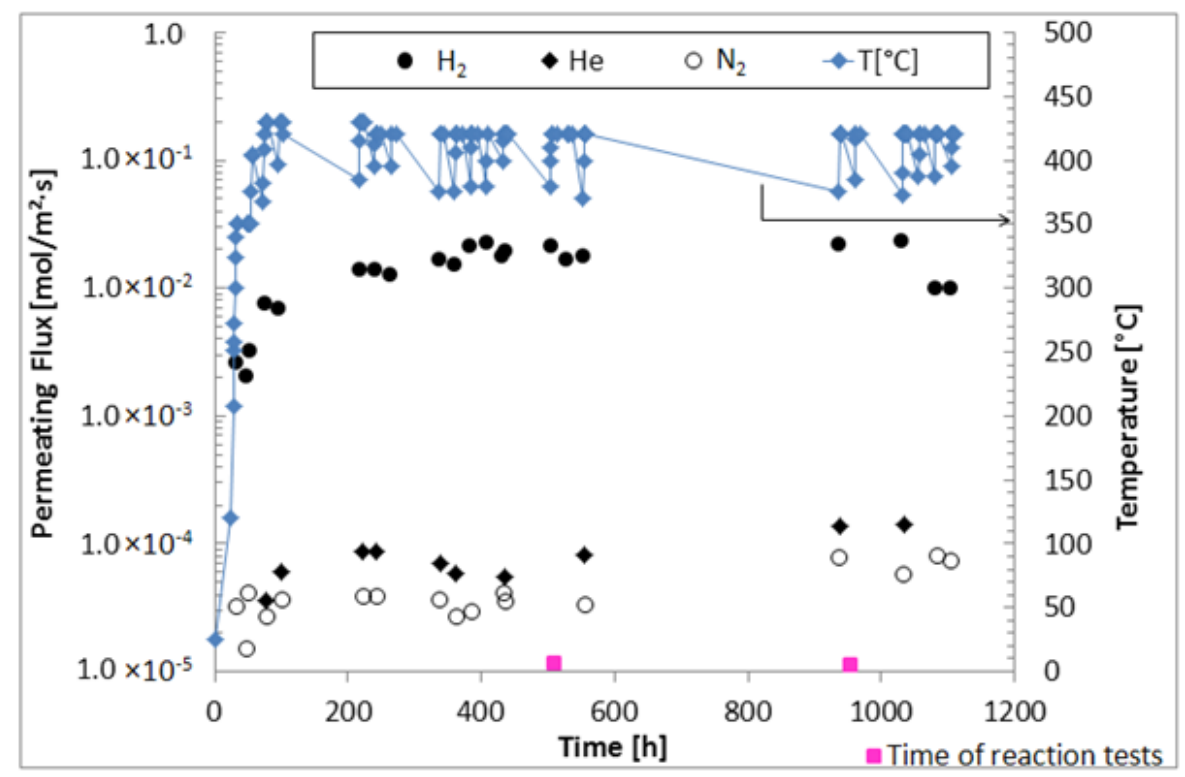

Figure 1. Pure $\mathrm{H}_{2}, \mathrm{~N}_{2}, \mathrm{He}$ permeating fluxes through the Pd-Au/PSS membrane and operating temperature vs. time. 
Then, in order to evaluate the permeation characteristic of the membrane at steady state conditions, further permeation tests with pure $\mathrm{N}_{2}, \mathrm{He}$ and $\mathrm{H}_{2}$ were successively performed and, after each cycle of pure gas permeation test, the composite membrane was flowed under hydrogen at $\Delta \mathrm{p}=50 \mathrm{kPa}$ also over night. The results of these tests in terms of $\mathrm{H}_{2}, \mathrm{~N}_{2}$ and He permeating fluxes are also resumed in Figure 1. As shown, in the range $0-100 \mathrm{~h}$, the $\mathrm{H}_{2}$ permeating flux increased from $\sim 2.0 \times 10^{-3} \mathrm{~mol} / \mathrm{m}^{2} \cdot \mathrm{s}$ to $7.5 \times 10^{-3} \mathrm{~mol} / \mathrm{m}^{2}$. s, due to the temperature increase from $300{ }^{\circ} \mathrm{C}$ to $420^{\circ} \mathrm{C}$. Afterwards, at the set temperature $\left(420^{\circ} \mathrm{C}\right)$ and with the composite membrane exposed to pure hydrogen permeation (a part from the daily realization of pure gas permeation tests), after $400 \mathrm{~h}$, the hydrogen permeating flux reached the steady state condition with an average value of $\sim 2.0 \times 10^{-2} \mathrm{~mol} / \mathrm{m}^{2} \cdot \mathrm{s}$, remaining constant up to $1100 \mathrm{~h}$. This trend confirms the optimum annealing conditions for the formation of Pd-Au alloy over this time [32]. As shown in Figure 2, $\mathrm{H}_{2} / \mathrm{N}_{2}$ and $\mathrm{H}_{2} / \mathrm{He}$ ideal selectivities increased in the range $0-100 \mathrm{~h}$ due to the higher operating temperature, consequently acting towards higher hydrogen permeating flux. After $300 \mathrm{~h}$ at $420^{\circ} \mathrm{C}$, they reached average values of around 500 and 220, respectively, remaining constant up to $1100 \mathrm{~h}$ under operation.

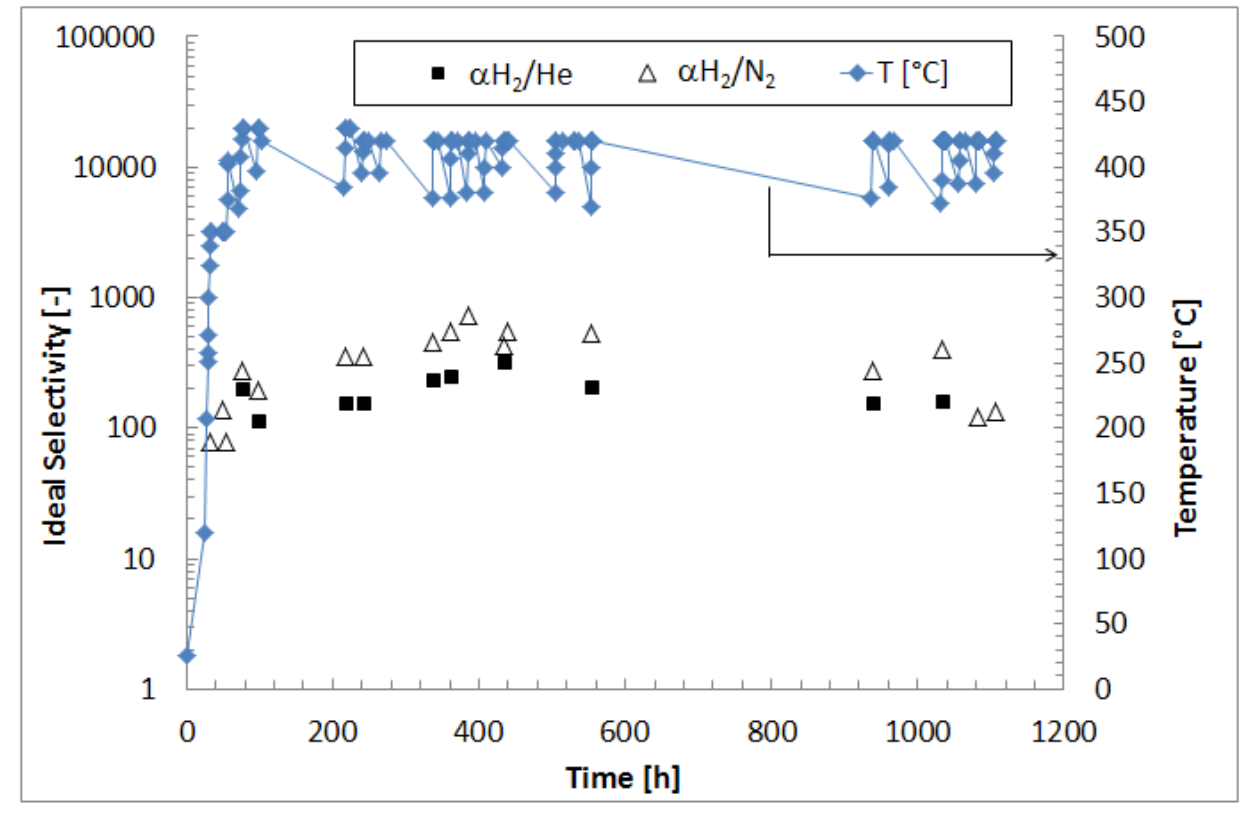

Figure 2. $\mathrm{H}_{2} / \mathrm{N}_{2}, \mathrm{H}_{2} / \mathrm{He}$ ideal selectivities for the Pd-Au/PSS membrane and operating temperature vs. time.

In the range $400-1000 \mathrm{~h}$, when the membrane showed constant properties in terms of hydrogen permeating flux and ideal selectivities, in order to define the correct value of $n$, a series of hydrogen permeation tests was performed at different transmembrane pressures to calculate the linear regression factor $\left(\mathrm{R}^{2}\right)$ at different " $n$ ". As illustrated in Figure 3, the highest value of $\mathrm{R}^{2}$ was reached at $n=1$, meaning that the permeation characteristics of the composite membrane are far from the Sieverts-Fick law [4], and, meanwhile, confirming a considerable presence of defects as pin-holes in the Pd-Au layer.

Furthermore, with the lifetime of the membrane around $1100 \mathrm{~h}$ under continuous operation, $\mathrm{CH}_{4}$ and $\mathrm{CO}_{2}$ permeation tests were also performed besides $\mathrm{H}_{2}$ and the results are summarized in Table 2 . As it was mentioned earlier, hydrogen permeates through the Pd-Au layer by a solution-diffusion mechanism. On the contrary, the other gases permeate through the defects of the Pd-Au surface and the pores of the support with a Knudsen diffusion mechanism [36]. 


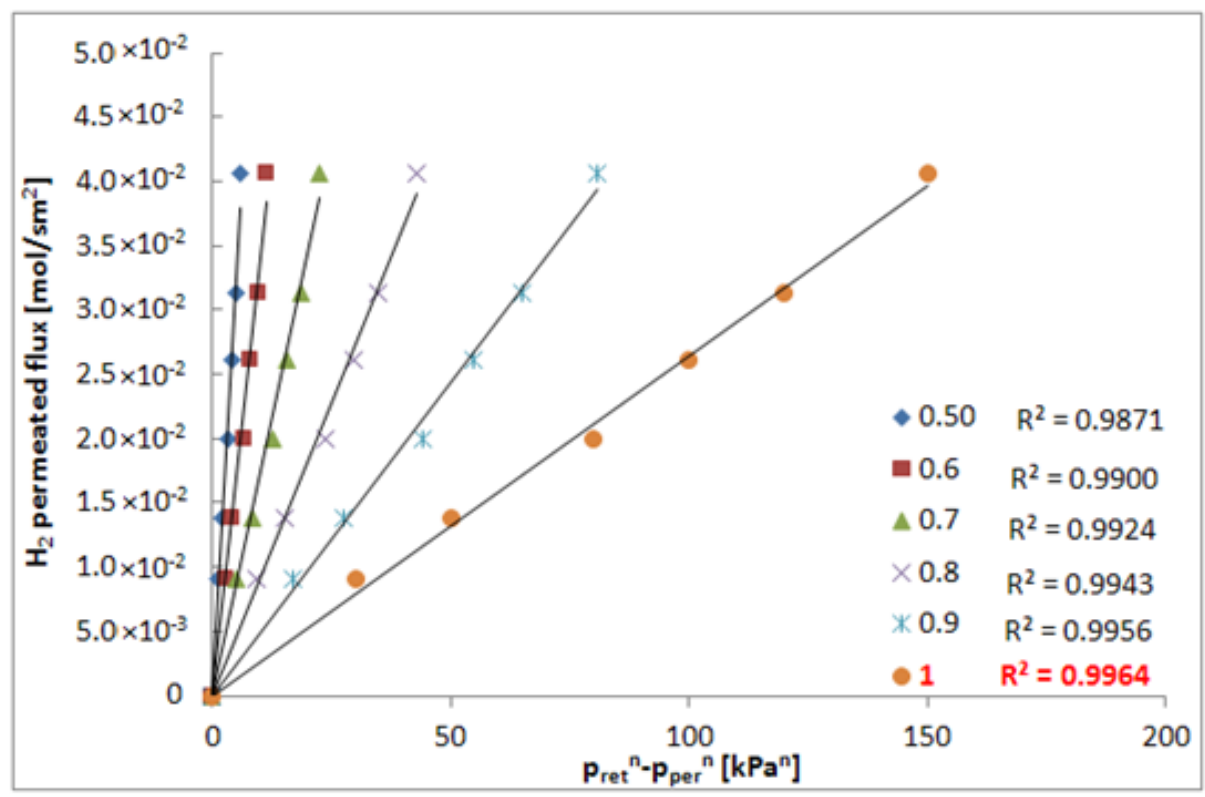

Figure 3. $\mathrm{H}_{2}$ permeating flux vs. the driving force at different " $\mathrm{n}$ " and $\mathrm{T}=420^{\circ} \mathrm{C}$.

Table 2. Permeation test results after $1100 \mathrm{~h}$ of composite membrane under continuous operation at $420^{\circ} \mathrm{C}$.

\begin{tabular}{ccccc}
\hline Pure Gas-i & $\begin{array}{c}\text { Molecular Weight } \\
(\mathbf{g} / \mathbf{m o l})\end{array}$ & $\begin{array}{c}\text { Transmembrane } \\
\text { Pressure } \mathbf{( k P a )}\end{array}$ & $\begin{array}{c}\text { Permeating Flux } \\
\left(\mathbf{m o l} / \mathbf{m}^{2} \cdot \mathbf{s}\right)\end{array}$ & $\boldsymbol{\alpha}_{\mathbf{H} 2 / \mathbf{i}}$ \\
\hline $\mathrm{H}_{2}$ & 2.00 & 50 & $2.3 \times 10^{-2}$ & 1 \\
$\mathrm{CH}_{4}$ & 16.04 & 50 & $8.6 \times 10^{-5}$ & 270 \\
$\mathrm{CO}_{2}$ & 44.01 & 50 & $4.7 \times 10^{-5}$ & 490 \\
\hline
\end{tabular}

The $\mathrm{H}_{2} / \mathrm{CO}_{2}$ ideal selectivity of a bit less than 500 represents an interesting result for the separation of hydrogen and carbon dioxide mixtures. However, only a few results are available in the open literature about $\mathrm{Pd}-\mathrm{Au}$ composite membranes applied in the field of gas separation and reaction testing, particularly evaluating the membrane aging. Then, a qualitative summary of the long-term characteristics of Pd-Au membranes from literature data are displayed in Table 3. Preparation method, thickness of the Pd-Au layer, operating conditions and $\mathrm{H}_{2}$ permeance as well as $\alpha_{\mathrm{H} 2 / \mathrm{He}}$ and reference are reported. As shown, the ideal selectivity $\alpha_{\mathrm{H} 2 / \mathrm{He}}$ of this work is the lowest compared to the other reported data, but it was calculated after almost $1000 \mathrm{~h}$ under operation, while the other data refer to the onset of the experimental tests or for a shorter range time under continuous operation.

Table 3. A comparison between the long term characteristics of different Pd-Au membranes

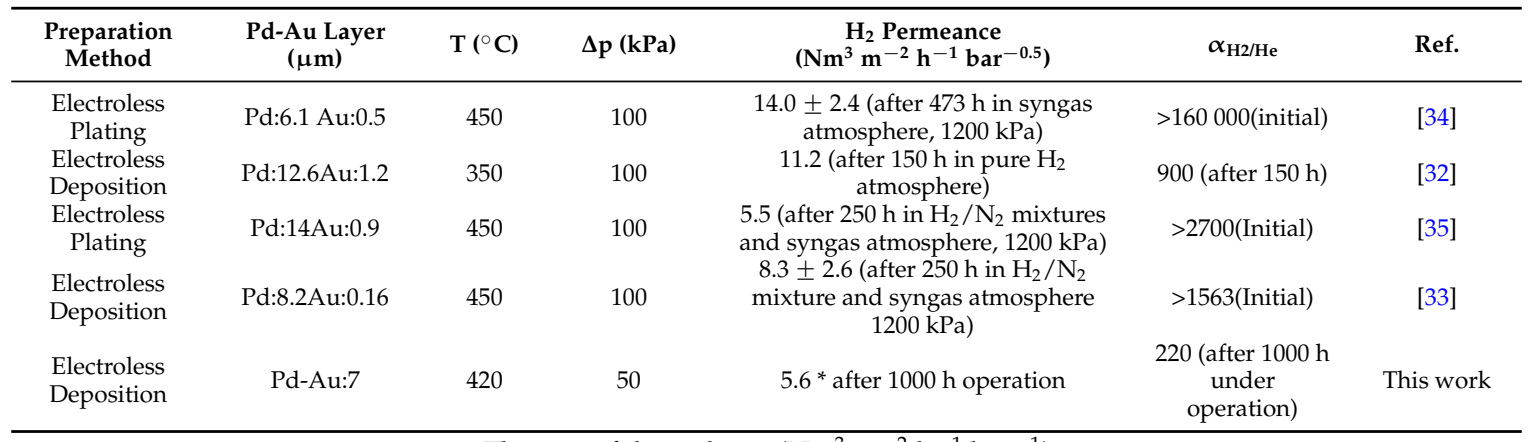

* The unit of this value is $\left(\mathrm{Nm}^{3} \mathrm{~m}^{-2} \mathrm{~h}^{-1} \mathrm{bar}^{-1}\right)$. 


\subsection{Methane Steam Reforming Reaction in the MR Housing the Pd-Au/PSS}

With the aim of examining the performance of the Pd-Au/PSS membrane in an MR, the MSR reaction was carried out (as reported by the square indicator in Figure 1) at $420{ }^{\circ} \mathrm{C}$ and $300 \mathrm{kPa}$ of reaction pressure by using also a sweep-gas in the permeate stream in counter-current mode with respect to the feed.

The endothermic reaction of MSR reaction can be expressed according to Equation (1):

$$
\mathrm{CH}_{4}+\mathrm{H}_{2} \mathrm{O}=\mathrm{CO}+3 \mathrm{H}_{2}, \Delta \mathrm{H}=206 \mathrm{~kJ} / \mathrm{mol}
$$

In the meanwhile, the water-gas shift (WGS) reaction takes place according to Equation (2):

$$
\mathrm{CO}+\mathrm{H}_{2} \mathrm{O}=\mathrm{CO}_{2}+\mathrm{H}_{2}, \Delta \mathrm{H}=-41.15 \mathrm{~kJ} / \mathrm{mol}
$$

Table 4 resumes the operating conditions of MSR reaction, and Figure 4 sketches the reaction results in terms of methane conversion, hydrogen recovery and yield.

\begin{tabular}{|c|c|}
\hline$\underset{\text { St }}{\mathrm{p}} \underset{\mathrm{p}}{\mathrm{p}}$ & \\
\hline $\mathrm{GHSV}^{*}=4100 \mathrm{~h}^{-1}$ & $\begin{array}{l}\mathrm{CH}_{4}=1.9 \times 10^{-3} \mathrm{~mol} / \mathrm{min} \\
\mathrm{H}_{2} \mathrm{O}=6.7 \times 10^{-3} \mathrm{~mol} / \mathrm{min}\end{array}$ \\
\hline
\end{tabular}

Table 4. Operating conditions during MSR reaction tests in the Pd-Au MR.

${ }^{*}$ Gas Hourly Space Velocity.

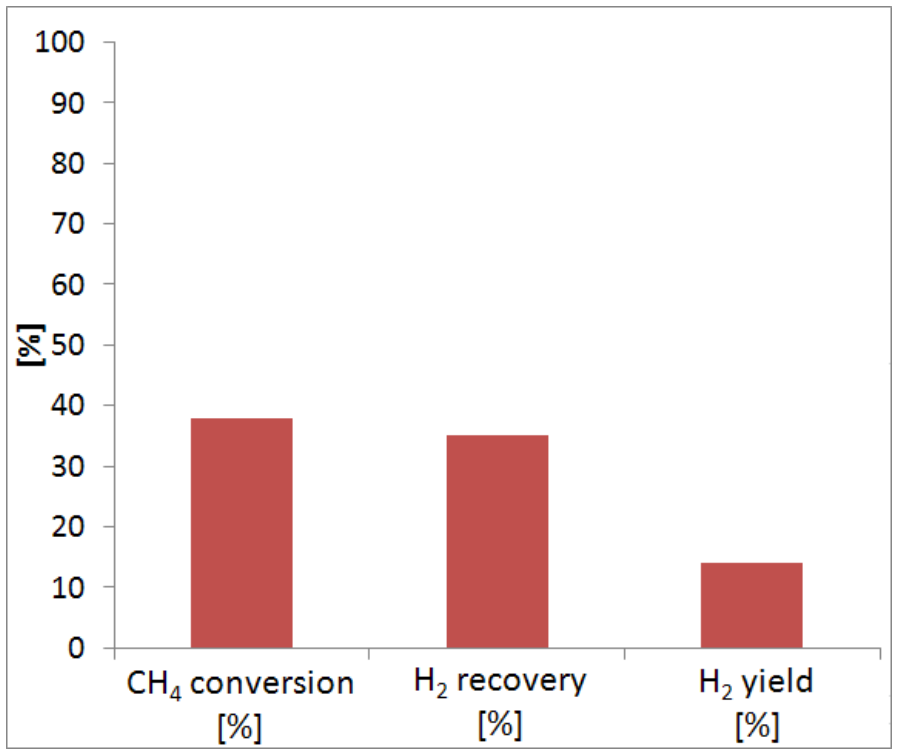

Figure 4. Methane conversion at $420{ }^{\circ} \mathrm{C}, 300 \mathrm{kPa}$ and GHSV $=4100 \mathrm{~h}^{-1}$ during MSR reaction in the Pd-Au MR.

The first reaction test was carried out at $420{ }^{\circ} \mathrm{C}, \mathrm{GHSV}=4100 \mathrm{~h}^{-1}$ and after $500 \mathrm{~h}$ of the membrane under pure gas permeation tests and with a constant hydrogen permeance. At these conditions, methane conversion is equal to $40 \%$ and the hydrogen recovery around $35 \%$, while the yield is around $15 \%$. The low conversion of methane is probably due to the low reaction temperature used during the tests. 
Furthermore, owing to a low value of hydrogen perm-selectivity the effect of the conversion shifting is not so much effective compared to dense Pd-based membranes, full hydrogen perm-selective. As a consequence, the hydrogen yield is also low as well as the hydrogen recovered in the permeated stream. Furthermore, as shown in Figure 5, the total hydrogen produced during the reaction was $0.84 \mathrm{~mL} / \mathrm{min}$, subdivided in the hydrogen in the permeate and retentate streams.

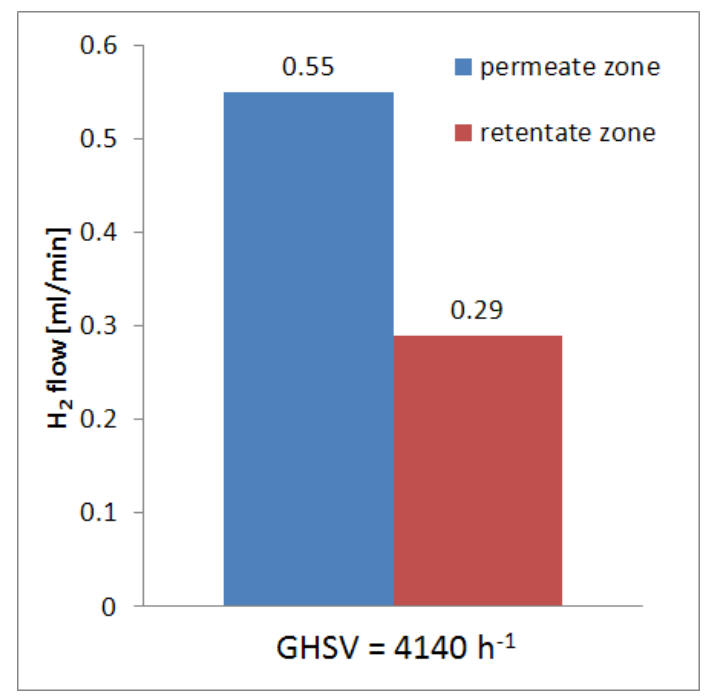

Figure 5. Hydrogen in the permeate and retentate streams during MSR reaction in the Pd-Au MR at $420{ }^{\circ} \mathrm{C}, 300 \mathrm{kPa}$ and GHSV $=4100 \mathrm{~h}^{-1}$.

All the results reported in Figures 4 and 5 show a maximum error bar lower than $2 \%$.

Hence, in order to improve the methane conversion, the space velocity was decreased to favor higher residence time of the reactants in the reaction zone with a consequent longer contact time between the gas mixture and the catalyst. Nevertheless, at GHSV $=1100 \mathrm{~h}^{-1}$ and $420^{\circ} \mathrm{C}$, the hydrogen recovery increased up to $65 \%$, but the conversion dropped to around $10 \%$. This reverse phenomena can be a sequence of catalyst deactivation due to coke formation.

As a consequence, the experimental tests at $1100 \mathrm{~h}^{-1}$ were repeated, and, once again, coke formation was verified. Then, after the reaction test, pure hydrogen was flowed into the reaction side $\left(\sim 3.0 \times 10^{-3} \mathrm{~mol} / \mathrm{min}\right)$ at $420^{\circ} \mathrm{C}$ and for around $2 \mathrm{~h}$.

Figure 6 shows the feed and retentate molar flow rates of hydrogen. The results show that, particularly, in the first hour of operation, a substantial part of hydrogen fed to the MR was consumed in the catalytic bed, forming methane and indirectly confirming the coke deposition during the experimental tests. Indeed, during the hydrogen feeding procedure, methane was detected by analyzing the retentate stream to the GC. Hence, after almost $1 \mathrm{~h}$ under operation, the flow rate of methane formed during this procedure decreased gradually till $2.25 \mathrm{~h}$, in which the inlet hydrogen stream was equal to the outlet stream. Successively, the reaction test was repeated, but the conversion remained still low and, then, the reaction tests were stopped. To verify the hydrogen permeation characteristic of the Pd-Au/PSS membrane after the reaction tests, permeation tests with pure $\mathrm{H}_{2}, \mathrm{~N}_{2}$ and He were further performed. Unfortunately, both $\alpha_{\mathrm{H} 2 / \mathrm{N} 2}$ and $\alpha_{\mathrm{H} 2 / \mathrm{He}}$ ideal selectivities dropped dramatically and, consequently, the MR was cooled down at ambient temperature, removing the membrane from the MR module. Figure 7 shows the status of the membrane before and after the experimental campaign, highlighting the color difference of the membrane surface, moved from the initial gold to gray.

Gade et al. [37] supposed that the presence of $\mathrm{H}_{2} \mathrm{~S}$ was responsible of the grain boundary attack with consequent loss of gold. However, the aforementioned authors stated that, in their opinion, the $\mathrm{H}_{2} \mathrm{~S}$ attack was not the sole mechanism as a cause of gold depletion as in the case of this work. 
Therefore, in a next study, we will investigate in details what could be the mechanism for the change in color of the membrane surface from gold to gray during such a reaction as MSR in absence of $\mathrm{H}_{2} \mathrm{~S}$ in the feed.

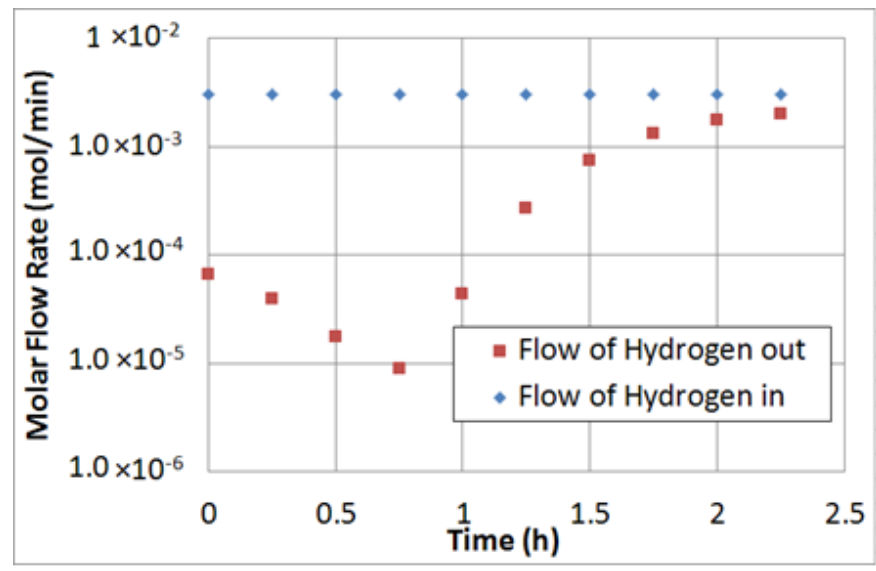

Figure 6. Molar flow rate of $\mathrm{H}_{2}$ in and out of the MR during coke deposition analysis.

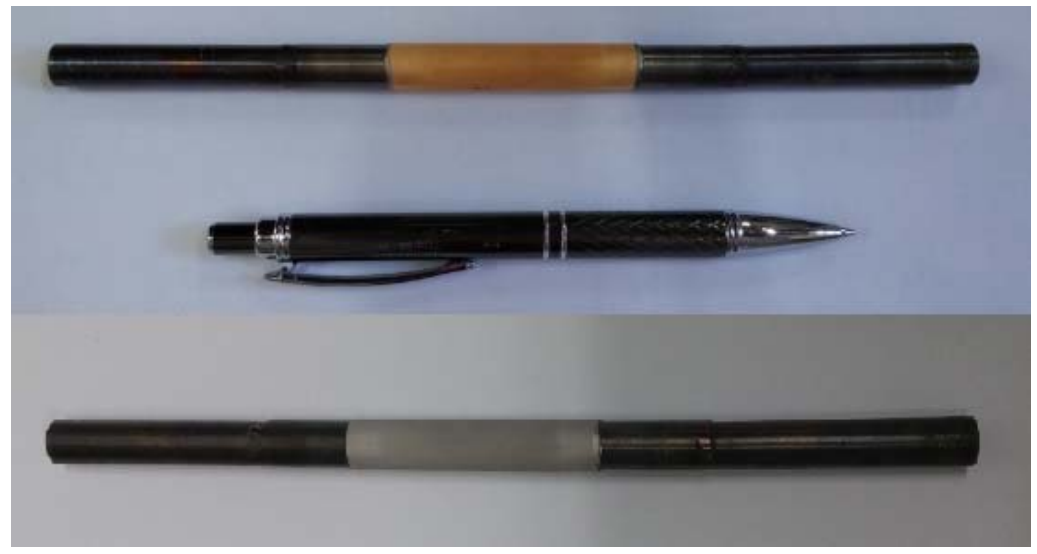

Figure 7. Picture of the supported Pd-Au membrane before tests (top) and after (bottom).

\section{Materials and Methods}

\subsection{Membrane Preparation}

Different techniques can be adopted for depositing palladium or its alloys onto porous substrates such as magnetron sputtering [38], spray pyrolysis [39], chemical vapor deposition (CVD) [40], physical vapor deposition [39,41] and electroless plating deposition (ELP) [42,43]. In this study, a dense Pd-Au layer ( $7 \mu \mathrm{m}$ thick) was deposited onto a PSS tubular support via the ELP method.

The support was supplied by Pall AccuSep (New York, NY, USA) having $1.0 \mathrm{~cm}$ O.D. (AISI 316L porous tube) with an active length around $4 \mathrm{~cm}$. The porous support was welded to two stainless steel tubes, and one of them is closed for facilitating the membrane housing in the MR module. Then, the total length of the membrane tube was $20 \mathrm{~cm}$. The support was oxidized for $12 \mathrm{~h}$ at $500{ }^{\circ} \mathrm{C}$. It was then graded with preactivated $\mathrm{Al}_{2} \mathrm{O}_{3}$ particles and cemented with $\mathrm{Pd}$ in order to decrease the surface pore size and narrow the surface pore size distribution and create the intermediate layer for avoiding intermetallic diffusion.

The surface activation was then carried out using the standard $\mathrm{SnCl}_{2}-\mathrm{PdCl}_{2}$ activation procedure and a thin layer of pure Pd was deposited by electroless plating technique. Successively, the Au deposition was performed by the method described in detail in Chen and Ma [29]. After each step of membrane preparation, the He permeance at room temperature was also measured (Figure $8 \mathrm{a}, \mathrm{b}$ ). 


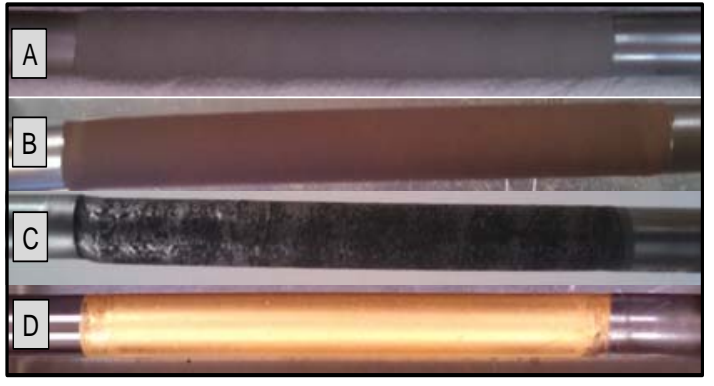

(a)

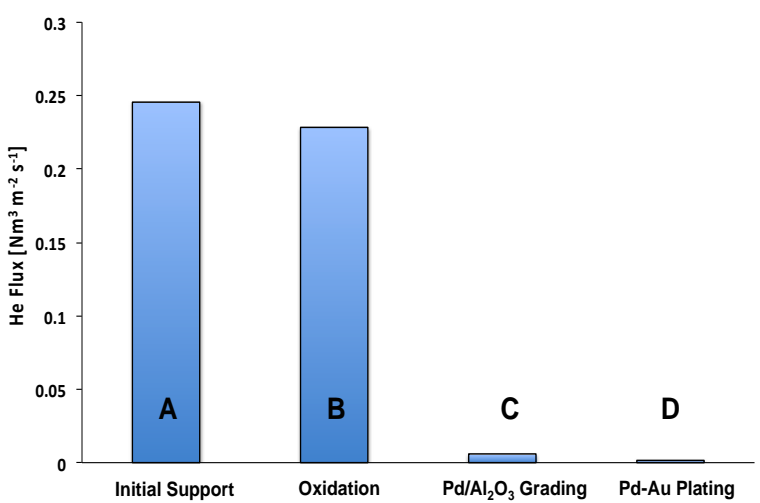

(b)

Figure 8. (a) fabrication Steps: [A] Initial support [B] Oxidation at $500{ }^{\circ} \mathrm{C}[\mathrm{C}]$ Grading [D] Final Pd-Au metallic layer; (b) He permeating flux during membrane progress $\left(\Delta \mathrm{p}=1\right.$ bar, $\left.\mathrm{T}=25^{\circ} \mathrm{C}\right)$.

Hence, the Pd-Au/PSS membrane was allocated in the module and fixed by means of graphite gaskets and $3.0 \mathrm{~g}$ of $\mathrm{Ni} / \mathrm{Al}_{2} \mathrm{O}_{3}$ commercial catalyst was packed in the annulus of the MR. To prevent the movement of catalyst particles, glass spheres were placed at each side of the catalytic bed.

The MR was flowed with pure $\mathrm{N}_{2}$ at ambient temperature to check the presence of leakages. A thermocouple was used to measure the temperature of the MR module, which was heated up by using two electrical tapes up to achieving the required temperatures $\left(300-420{ }^{\circ} \mathrm{C}\right)$. The retentate pressure was adjusted by utilizing a back-pressure regulator placed at the outlet side of this stream, while the permeate pressure was always kept at $100 \mathrm{kPa}$.

A scheme of the experimental setup used in this work is illustrated in Figure 9. In the case of permeation tests, pure gases $\left(\mathrm{H}_{2}, \mathrm{~N}_{2}, \mathrm{He}, \mathrm{CH}_{4}\right.$ or $\left.\mathrm{CO}_{2}\right)$ were flowed into the MR module and the permeating flow rate was measured by means of bubble flow meters.

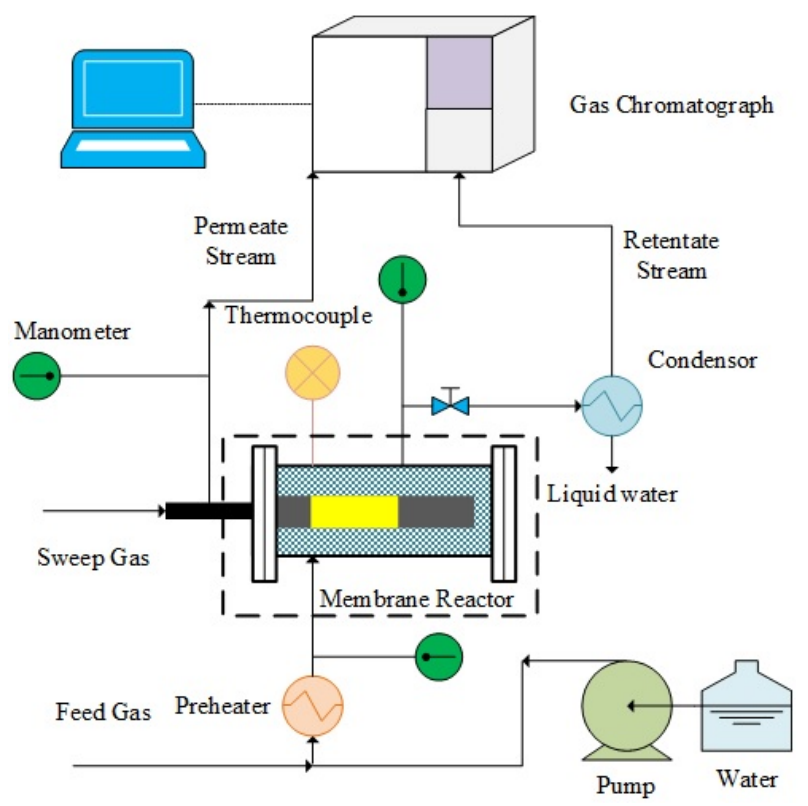

Figure 9. Schematic view of the experimental setup used for permeation and MSR reaction tests.

During the reaction tests of MSR, methane was mixed with deionized water (steam/ methane $=3.5 / 1$ ), which was pumped by a P680 HPLC pump (Dreieich, Germany), in a preheated chamber and, then, injected to the reaction zone. $\mathrm{N}_{2}$ was also used as an internal standard gas and as a 
sweep gas with a flow rate of $\sim 25 \mathrm{~mL} / \mathrm{min}$, flowed in counter-current mode with respect to the feed. To remove the unreacted water from the retentate and, eventually, from the permeate streams, they were passed through a condenser. Then, the retentate and permeate dry streams were analyzed by means of a temperature programmed HP 6890 gas chromatograph (GC) (Foster City, CA, USA). Each experimental point reported in this work was constituted of, at least, ten reaction cycles at the same operating conditions in order to ensure the reproducibility of the results.

\subsection{Permeation Tests}

Pure gases such as $\mathrm{H}_{2}, \mathrm{~N}_{2}, \mathrm{He}, \mathrm{CH}_{4}$ or $\mathrm{CO}_{2}$ were flowed into the membrane reactor module before reaction tests for studying the permeation characteristics of the supported Pd-Au membrane.

The pure gases were provided by cylinders.

To analyze the hydrogen permeation characteristics of the Pd-Au/PSS membrane, Equation (3) was used as:

$$
\mathrm{J}_{\mathrm{H} 2}=\mathrm{P}_{\mathrm{H} 2}\left(\mathrm{p}^{\mathrm{n}}{ }_{\mathrm{H} 2 \text {,retentate }}-\mathrm{p}^{\mathrm{n}}{ }_{\mathrm{H} 2 \text {, permeate }}\right)
$$

where $J_{H 2}$ is the hydrogen flux permeating through the membrane, $P_{H 2}$ the hydrogen permeance, $p_{H 2, \text { reaction }}$ and $p_{H 2, \text { permeate }}$ the hydrogen partial pressures in the reaction and permeate sides, respectively. $n$ is variable in the range $0.5-1$ depending on the rate limiting step of hydrogen diffusion. More details about the deviation of Sieverts-Fick law $(n=0.5)$ were explained elsewhere [44].

The hydrogen over other pure gas ideal selectivity $\left(\alpha_{\mathrm{H} 2 / \mathrm{i}}\right)$ was expressed as the ratio of the $\mathrm{H}_{2}$ permeating flux over the permeating flux of another pure gas of interest at the same transmembrane pressure, as reported in Equation (4):

$$
\alpha_{\mathrm{H} 2 / \mathrm{i}}=\mathrm{J}_{\mathrm{H} 2} / \mathrm{J}_{\mathrm{i}}, \mathrm{i}=\left(\mathrm{He}, \mathrm{N}_{2}, \mathrm{CO}_{2}, \mathrm{CH}_{4}\right)
$$

Methane conversion was described by using Equation (5) during MSR reaction:

$$
\text { Conversion }(\%)=\left[\left(\mathrm{CO}_{\text {out }}+\mathrm{CO}_{2 \text { out }}\right) / \mathrm{CH}_{4} \text { in }\right] \times 100
$$

where $\mathrm{CO}_{\text {out }}$ and $\mathrm{CO}_{2}$ out represent the outlet molar flow rates of $\mathrm{CO}$ and $\mathrm{CO}_{2}$, while $\mathrm{CH}_{4}$,in represents the molar flow rate of methane in the reaction side.

Hydrogen recovery was defined by Equation (6):

$$
\text { Hydrogen Recovery }(\%)=\left[\mathrm{H}_{2 \text {-perm }} /\left(\mathrm{H}_{2 \text {-perm }}+\mathrm{H}_{2 \text {-ret }}\right)\right] \times 100
$$

where $\mathrm{H}_{2 \text {-perm }}$ and $\mathrm{H}_{2 \text {-ret }}$ are the molar flow rates of hydrogen in the permeate and retentate streams, respectively.

\section{Conclusions}

We investigated the performance of a supported $\mathrm{Pd}-\mathrm{Au}$ membrane in terms of hydrogen permeance and ideal selectivity in pure gas permeation tests under long time continuous operation. The hydrogen permeance increased till achieving steady state conditions after around $400 \mathrm{~h}$. Hence, at $50 \mathrm{kPa}$ of transmembrane pressure and $420{ }^{\circ} \mathrm{C}$, the composite membrane reached $\mathrm{H}_{2} / \mathrm{N}_{2}$ ideal selectivity of around 500 with an hydrogen permeance of $2.3 \times 10^{-2} \mathrm{~mol} / \mathrm{m}^{2} \cdot \mathrm{s}$, remaining stable up to $1100 \mathrm{~h}$ under operation.

During MSR reaction tests, 40\% of methane conversion and 35\% of hydrogen recovery were reached in the MR. However, coke was formed during the reaction tests, and it was probably responsible of the irreversible loss of hydrogen permeation characteristics of the membrane. The MR was cooled at ambient temperature, and we observed that the color of the membrane surface moved from gold to gray. In the future, we will better investigate this effect, making more stable the alloy during the reaction tests, meanwhile, improving the hydrogen permeation selectivity. 
Acknowledgments: The authors would like to thank Prof. Yi Hua Ma and Ivan P. Mardilovich for the Pd-Au/PSS membrane preparation at the Worcester Polytechnique Institute (Worcester, MA, USA).

Author Contributions: A.I. partially wrote the manuscript and made the analysis of the experimental data; M.A. partially wrote the manuscript and participated to the experimental campaign. G.B., S.L. and B.A. participated to the experimental campaign, J.W., M.R.R. and R.E. contributed to the manuscript preparation, and A.B. managed the whole manuscript.

Conflicts of Interest: The authors declare no conflict of interest.

\section{Nomenclature}

Symbol
B
dp
$\mathrm{D}_{\mathrm{ki}}$
$\mathrm{J}$
$\mathrm{M}$
$\mathrm{p}$
$\mathrm{P}$
$\mathrm{t}$
$\mathrm{T}$

\section{Greek Letters}

Definition
Permeability
Pore Diameter
Knudsen Diffusivity
Permeation Flux
Molecular Weight
Partial Pressure
Total Pressure
Time
Temperature

Unit
$\mathrm{mol} \cdot \mathrm{m}^{-1} \cdot \mathrm{s}^{-1} \cdot \mathrm{kPa}^{-\mathrm{n}}$
$\mathrm{m}$
$\mathrm{m}^{2} \cdot \mathrm{s}^{-2}$
$\mathrm{~mol} \cdot \mathrm{m}^{-2} \cdot \mathrm{s}^{-1}$
$\mathrm{~kg} / \mathrm{mol}$
$\mathrm{kPa}$
$\mathrm{kPa}$
$\mathrm{h}$
${ }^{\circ} \mathrm{C}$

$\begin{array}{lll}\text { Symbol } & \text { Definition } & \text { Unit } \\ \alpha & \text { Ideal Selectivity } & \\ \delta & \text { Membrane Thickness } & \mathrm{m}\end{array}$

\section{Subscripts}

$\begin{array}{ll}\text { Symbol } & \text { Definition } \quad \text { Unit } \\ \text { i } & \text { Species }\end{array}$

\section{Abbreviations}

$\begin{array}{ll}\text { GC } & \text { Gas Chromatograph } \\ \text { GHSV } & \text { Gas Hourly Space Velocity } \\ \text { MR } & \text { Membrane Reactor } \\ \text { MSR } & \text { Methane Steam Reforming } \\ \text { PSS } & \text { Porous Stainless Steel }\end{array}$

\section{References}

1. Briceño, K.; Iulianelli, A.; Montané, D.; Garcia-Valls, R.; Basile, A. Carbon molecular sieve membranes supported on non-modified ceramic tubes for hydrogen separation in membrane reactors. Int. J. Hydrog. Energy 2012, 37, 13536-13544. [CrossRef]

2. Ghasemzadeh, K.; Morrone, P.; Iulianelli, A.; Liguori, S.; Babaluo, A.A.; Basile, A. $\mathrm{H}_{2}$ production in silica membrane reactor via methanol steam reforming: Modeling and HAZOP analysis. Int. J. Hydrog. Energy 2013, 38, 10315-10326. [CrossRef]

3. Illgen, U.; Schäfer, R.; Noack, M.; Kölsch, P.; Kühnle, A.; Caro, J. Membrane supported catalytic dehydrogenation of iso-butane using an MFI zeolite membrane reactor. Catal. Commun. 2001, 2, 339-345. [CrossRef]

4. Basile, A.; Iulianelli, A.; Longo, T.; Liguori, S.; de Falco, M. Pd-based selective membrane state-of-the-art. In Membrane Reactors for Hydrogen Production Processes; Marrelli, L., De Falco, M., Iaquaniello, G., Eds.; Springer: New York, NY, USA, 2011; Chapter 2; pp. 21-55. ISBN: 978-0-85729-150-9. 
5. Li, A.; Gracem, J.R.; Lim, C.J. Preparation of thin Pd-based composite membrane on planar metallic substrate: Part II. Preparation of membranes by electroless plating and characterization. J. Membr. Sci. 2007, 306, 159-165. [CrossRef]

6. Flanagan, T.B.; Oates, W.A. The Palladium-Hydrogen System. Annu. Rev. Mater. Sci. 1991, 21, $269-304$. [CrossRef]

7. Nguyen, T.H.; Mori, S.; Suzuki, M. Hydrogen permeance and the effect of $\mathrm{H}_{2} \mathrm{O}$ and $\mathrm{CO}$ on the permeability of $\mathrm{Pd}_{0.75} \mathrm{Ag}_{0.25}$ membranes under gas-driven permeation and plasma-driven permeation. Chem. Eng. J. 2009, 155, 55-61. [CrossRef]

8. Amandusson, H.; Ekedahl, L.G.; Dannetun, H. The effect of $\mathrm{CO}$ and $\mathrm{O}_{2}$ on hydrogen permeation through a palladium membrane. Appl. Surf. Sci. 2000, 153, 259-267. [CrossRef]

9. Sakamoto, Y.; Chen, F.L.; Kinari, Y.; Sakamoto, F. Effect of carbon monoxide on hydrogen permeation in some palladium-based alloy membranes. Int. J. Hydrog. Energy 1996, 21, 1017-1024. [CrossRef]

10. Wang, D.; Flanagan, T.B.; Shanahan, K.L. Permeation of hydrogen through pre-oxidized Pd membranes in the presence and absence of CO. J. Alloys Compd. 2004, 372, 158-164. [CrossRef]

11. Catalano, J.; Giacinti Baschetti, M.; Sarti, G.C. Influence of water vapor on hydrogen permeation through $2.5 \mu \mathrm{m}$ Pd-Ag membranes. Int. J. Hydrog. Energy 2011, 36, 8658-8673. [CrossRef]

12. Gielens, F.C.; Knibbeler, R.J.J.; Duysinx, P.F.J.; Tong, H.D.; Vorstman, M.A.G.; Keurentjes, J.T.F. Influence of steam and carbon dioxide on the hydrogen flux through thin Pd/Ag and Pd membranes. J. Membr. Sci. 2006, 279, 176-185. [CrossRef]

13. Heras, J.M.; Estiú, G.; Viscido, L. The interaction of water with clean palladium films: A thermal desorption and work function study. Appl. Surf. Sci. 1997, 108, 455-464. [CrossRef]

14. Ali, J.K.; Newson, E.J.; Rippin, D.W.T. Deactivation and regeneration of Pd-Ag membranes for dehydrogenation reactions. J. Membr. Sci. 1994, 89, 171-184. [CrossRef]

15. Sakamoto, F.; Kinari, Y.; Chen, F.L.; Sakamoto, Y. Hydrogen permeation through palladium alloy membranes in mixture gases of $10 \%$ nitrogen and ammonia in the hydrogen. Int. J. Hydrog. Energy 1997, 22, 369-375. [CrossRef]

16. Edlund, D.J.; Pledger, W.A. Thermolysis of hydrogen sulfide in a metal-membrane reactor. J. Membr. Sci. 1993, 77, 255-264. [CrossRef]

17. Burke, M.L.; Madix, R.J. Hydrogen on Pd(100)-S: The effect of sulfur on precursor mediated adsorption and desorption. Surf. Sci. 1990, 237, 1-19. [CrossRef]

18. Kajiwara, M.; Uemiya, S.; Kojima, T. Stability and hydrogen permeation behavior of supported platinum membranes in presence of hydrogen sulfide. Int. J. Hydrog. Energy 1999, 24, 839-844. [CrossRef]

19. Bryden, K.J.; Ying, J.Y. Nanostructured palladium-iron membranes for hydrogen separation and membrane hydrogenation reactions. J. Membr. Sci. 2002, 203, 29-42. [CrossRef]

20. Lewis, A.E.; Kershner, D.C.; Paglieri, S.N.; Slepicka, M.J.; Way, J.D. Pd-Pt/YSZ composite membranes for hydrogen separation from synthetic water-gas shift streams. J. Membr. Sci. 2013, 437, 257-264. [CrossRef]

21. She, Y.; Emerson, S.C.; Magdefrau, N.J.; Opalka, S.M.; Thibaud-Erkey, C.; Vanderspurt, T.H. Hydrogen permeability of sulfur tolerant Pd-Cu alloy membranes. J. Membr. Sci. 2014, 452, 203-211. [CrossRef]

22. Okazaki, J.; Tanaka, D.A.P.; Tanco, M.A.L.; Wakui, Y.; Mizukami, F.; Suzuki, T.M. Hydrogen permeability study of the thin Pd-Ag alloy membranes in the temperature range across the $\alpha-\beta$ phase transition. J. Membr. Sci. 2006, 282, 370-374. [CrossRef]

23. Kamakoti, P.; Morreale, B.D.; Ciocco, M.V.; Howard, B.H.; Killmeyer, R.P.; Cugini, A.V.; Sholl, D.S. Prediction of hydrogen flux through sulfur-tolerant binary alloy membranes. Science 2005, 307, 569-573. [CrossRef] [PubMed]

24. Kamakoti, P.; Sholl, D.S. Ab initio lattice-gas modeling of interstitial hydrogen diffusion in CuPd alloys. Phys. Rev. B 2005, 71. [CrossRef]

25. Semidey-Flecha, L.; Sholl, D.S. Combining density functional theory and cluster expansion methods to predict $\mathrm{H} 2$ permeance through Pd-based binary alloy membranes. J. Chem. Phys. 2008, 128. [CrossRef] [PubMed]

26. Mckinley, D.L. Metal Alloy for Hydrogen Separation and Purification. U.S. Patent 3,350,845, 7 November 1967.

27. Mckinley, D.L. Method for Hydrogen Separation and Purification. U.S. Patent 3,439,474, 22 April 1969. 
28. Way, J.; Lusk, M.; Thoen, P. Sulfur-Resistant composite Metal Membranes. U.S. Patent 2008/0038567 A1, 14 February 2008.

29. Chen, C.-H.; Ma, Y.H. The effect of $\mathrm{H}_{2} \mathrm{~S}$ on the performance of Pd and Pd/Au composite membrane. J. Membr. Sci. 2010, 362, 535-544. [CrossRef]

30. Sonwane, C.G.; Wilcox, J.; Ma, Y.H. Achieving optimum hydrogen permeability in PdAg and PdAu alloys. J. Chem. Phys. 2006, 125. [CrossRef] [PubMed]

31. Gryaznov, V. Metal containing membranes for the production of ultrapure hydrogen and the recovery of hydrogen isotopes. Sep. Purif. Rev. 2000, 29, 171-187. [CrossRef]

32. Ma, Y.H.; Chen, C.-H.; Catalano, J.; Guazzone, F.; Payzant, E.A. Synthesis, annealing, and performances of Pd-Au asymmetric composite membranes for hydrogen purification. Ind. Eng. Chem. Res. 2013, 52, 8732-8744. [CrossRef]

33. Guazzone, F.; Catalano, J.; Mardilovich, I.P.; Kniep, J.; Pande, S.; Wu, T.; Lambrecht, R.C.; Datta, S.; Kazantzis, N.K.; Ma, Y.H. Gas permeation field tests of composite Pd and Pd-Au membranes in actual coal derived syngas atmosphere. Int. J. Hydrog. Energy 2012, 37, 14557-14568. [CrossRef]

34. Guazzone, F.; Catalano, J.; Mardilovich, I.P.; Wu, T.; Lambrecht, R.C.; Datta, S.; Kniep, J.; Pande, S.; Kazantzis, N.K.; Ma, Y.H. Enhancement of the long-term permeance, selectivity stability, and recoverability of Pd-Au membranes in coal derived syngas atmospheres. Energy Fuels 2013, 27, 4150-4160. [CrossRef]

35. Mardilovich, I.P.; Castro-Dominguez, B.; Kazantzis, N.K.; Wu, T.; Ma, Y.H. A comprehensive performance assessment study of pilot-scale $\mathrm{Pd}$ and $\mathrm{Pd} /$ alloy membranes under extended coal-derived syngas atmosphere testing. Int. J. Hydrog. Energy 2015, 40, 6107-6117. [CrossRef]

36. Abedini, R.; Nezhadmoghadam, A. Application of membrane in gas separation process: Its suitability and mechanisms. Pet. Coal 2010, 52, 69-80.

37. Gade, S.K.; DeVoss, S.J.; Coulter, K.E.; Paglieri, S.N.; Alptekin, G.O.; Way, J.D. Palladium-gold membranes in mixed gas streams with hydrogen sulfide: Effect of alloy content and fabrication technique. J. Membr. Sci. 2011, 378, 35-41. [CrossRef]

38. Peters, T.A.; Stange, M.; Bredesen, R. Fabrication of palladium-based membranes by magnetron sputtering. In Palladium Membrane Technology for Hydrogen Production, Carbon Capture and Other Applications: Principles, Energy Production and Other Applications; Doukelis, A., Panopoulos, K., Koumanakos, A., Kakaras, E., Eds.; Elsevier Ltd.: Amsterdam, The Netherlands, 2014; Chapter 2; pp. 1-383. ISBN: 978-178242241-9; 978-178242234-1.

39. Li, Z.Y.; Maeda, H.; Kusakabe, K.; Morooka, S.; Anzai, H.; Akiyama, S. Preparation of palladium-silver alloy membranes for hydrogen separation by the spray pyrolysis method. J. Membr. Sci. 1993, 78, 247-254. [CrossRef]

40. Jun, C.S.; Lee, K.H. Palladium and palladium alloy composite membranes prepared by metal-organic chemical vapour deposition method (cold-wall). J. Membr. Sci. 2000, 176, 121-130. [CrossRef]

41. Broglia, M.; Pinacci, P.; Radaelli, M.; Bottino, A.; Capannelli, G.; Comite, A.; Vanacore, G.; Zani, M. Synthesis and characterization of Pd membranes on alumina-modified porous stainless steel supports. Desalination 2009, 245, 508-515. [CrossRef]

42. Cheng, Y.S.; Yeung, K.L. Effects of electroless plating chemistry on the synthesis of palladium membranes. J. Membr. Sci. 2001, 182, 195-203. [CrossRef]

43. Zhang, X.; Xiong, G.; Yang, W. A modified electroless plating technique for thin dense palladium composite membranes with enhanced stability. J. Membr. Sci. 2008, 314, 67-84. [CrossRef]

44. Liguori, S.; Iulianelli, S.; Dalena, F.; Pinacci, P.; Drago, F.; Broglia, M.; Huang, Y.; Basile, A. Performance and long-term stability of $\mathrm{Pd} / \mathrm{PSS}$ and $\mathrm{Pd} / \mathrm{Al}_{2} \mathrm{O}_{3}$ for hydrogen separation. Membranes 2014, 4, 143-162. [CrossRef] [PubMed]

Sample Availability: Not available.

(C) 2016 by the authors; licensee MDPI, Basel, Switzerland. This article is an open access article distributed under the terms and conditions of the Creative Commons Attribution (CC-BY) license (http://creativecommons.org/licenses/by/4.0/). 